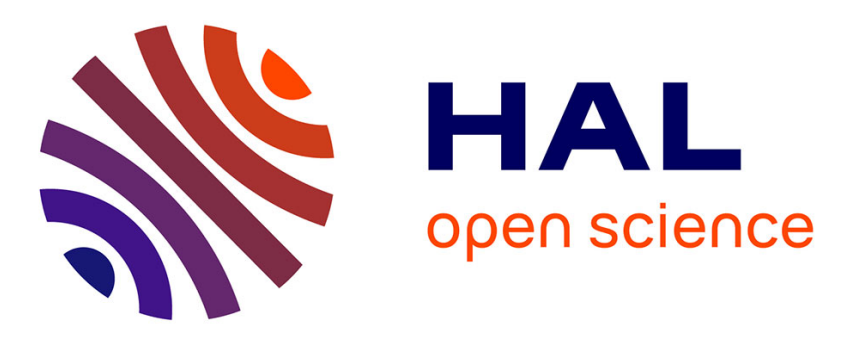

\title{
Sucrose phosphorylase as a cross-linked enzyme aggregate: Improved thermal stability for industrial applications
}

\author{
an G Cerdobbel, Karel de Winter, Tom Desmet, Wim Soetaert
}

\section{To cite this version:}

an G Cerdobbel, Karel de Winter, Tom Desmet, Wim Soetaert. Sucrose phosphorylase as a cross-linked enzyme aggregate: Improved thermal stability for industrial applications. Biotechnology Journal, 2010, 5 (11), pp.1192. 10.1002/biot.201000202 . hal-00579475

HAL Id: hal-00579475

https://hal.science/hal-00579475

Submitted on 24 Mar 2011

HAL is a multi-disciplinary open access archive for the deposit and dissemination of scientific research documents, whether they are published or not. The documents may come from teaching and research institutions in France or abroad, or from public or private research centers.
L'archive ouverte pluridisciplinaire HAL, est destinée au dépôt et à la diffusion de documents scientifiques de niveau recherche, publiés ou non, émanant des établissements d'enseignement et de recherche français ou étrangers, des laboratoires publics ou privés. 


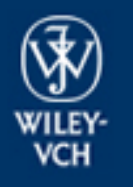

Biotechnology Journal

\section{Sucrose phosphorylase as a cross-linked enzyme aggregate: Improved thermal stability for industrial applications}

\begin{tabular}{|r|l|}
\hline Journal: & Biotechnology Journal \\
\hline Manuscript ID: & biot.201000202.R1 \\
\hline Wiley - Manuscript type: & Research Article \\
\hline Author: & 19-Aug-2010 \\
\hline Complete List of Authors: & $\begin{array}{l}\text { Cerdobbel, An } \\
\text { De Winter, Karel; Ghent University } \\
\text { Desmet, Tom; Ghent University } \\
\text { Soetaert, Wim; Ghent University }\end{array}$ \\
\hline Primary Keywords: & White/Industrial Biotechnology \\
\hline Secondary Keywords: & Biocatalysis \\
\hline Keywords: & Immobilization \\
\hline
\end{tabular}

\section{SCHOLARONE ${ }^{m}$ \\ Manuscripts}




\title{
Sucrose phosphorylase as cross-linked enzyme aggregate: Improved thermal stability for industrial applications
}

An Cerdobbel*, Karel De Winter, Tom Desmet, Wim Soetaert

Centre of Expertise for Industrial Biotechnology and Biocatalysis, Department of Biochemical and Microbial Technology, Faculty of Biosciences Engineering, Ghent University, Coupure Links 653, B-9000 Ghent, Belgium

*Corresponding author:

Tel.: +3292649921; Fax: +3292646032; E-mail: an.cerdobbel@ugent.be

\section{Keywords}

CLEA, sucrose phosphorylase, thermostability, enzyme immobilization, biocatalysis

\begin{abstract}
Abbreviations
SPase: sucrose phosphorylase; G1P: $\alpha$-glucose-1-phosphate; GA: glutaraldehyde; CLEA: cross-linked enzyme aggregate
\end{abstract}




\begin{abstract}
Sucrose phosphorylase is an interesting biocatalyst that can glycosylate a variety of small molecules using sucrose as a cheap but efficient donor substrate. The low thermostability of the enzyme, however, limits its industrial applications, as these are preferably performed at $60{ }^{\circ} \mathrm{C}$ to avoid microbial contamination. Cross-linked enzyme aggregates (CLEAs) of the sucrose phosphorylase from Bifidobacterium adolescentis were found to have a temperature optimum that is $17{ }^{\circ} \mathrm{C}$ higher than that of the soluble enzyme. Furthermore, the immobilized enzyme displays an exceptional thermostability, retaining all of its activity after one week incubation at $60{ }^{\circ} \mathrm{C}$. Recycling of the biocatalyst allows its use in at least ten consecutive reactions, which should dramatically increase the commercial potential of its glycosylating activity.
\end{abstract}




\section{Introduction}

Enzymes are powerful biocatalysts that find increasing applications in various industrial processes. The major advantages of the use of enzymes for chemical transformations are their high chemo-, regio- and stereospecificity, as well as their environmentally friendly properties. Unfortunately, natural enzymes are often not optimally suited for industrial applications, which can be hampered by their lack of long-term stability under process conditions and by their difficult recovery and recycling. These drawbacks can, however, be overcome by immobilization of the enzymes [1-4].

Cross-linked enzyme aggregates (CLEAs) have emerged as a novel class of immobilized biocatalysts for use in both aqueous and non-aqueous environments [5]. Such preparations are obtained by the physical aggregation of the enzymes followed by chemical cross-linking (Fig. 1). This procedure allows enzymes to be immobilized without the use of a carrier, which not only decreases the cost but also avoids "dilution" of the enzymes' activity [6]. CLEAs share their beneficial properties with cross-linked enzyme crystals (CLECs) but do not require tedious crystallization procedures $[7,8]$.

Sucrose phosphorylase (SPase) catalyses the reversible phosphorolysis of sucrose into $\alpha$-D-glucose-1-phosphate (G1P) and fructose. This enzyme is mainly found in lactic acid bacteria and bifidobacteria, where it contributes to an efficient energy metabolism [9]. SPase is formally classified as a glycosyl transferase (EC 2.4.1.7), 
although it belongs to glycoside hydrolase family 13 [10] and follows the typical double displacement mechanism of retaining glycosidases [11]. The crystal structure of the enzyme from Bifidobacterium adolescentis has been determined and consists of a $(\beta / \alpha)_{8}$ barrel containing two carboxylic amino acids as catalytic residues [12].

A number of practical applications have been developed for SPase [13, 14]. The enzyme has long been used for the production of G1P, an efficient donor for chemical and enzymatic glycosylation reactions [15]. Furthermore, SPase can also transfer a glucosyl group to different carbohydrate and non-carbohydrate acceptors thanks to its broad substrate specificity [16, 17]. Goedl et al., for example, have developed an exceptionally efficient and selective process for the production of glyceryl $\alpha$-D-glucoside, a moisturizing agent for cosmetics that is marketed under the tradename Glycoin ${ }^{\circledR}[18,19]$.

Unfortunately, no SPases have so far been reported that can resist the extreme process conditions that are preferred by the industry. Indeed, carbohydrate conversions are typically performed at elevated temperatures $\left(60{ }^{\circ} \mathrm{C}\right.$ or higher $)$, mainly to avoid microbial contamination [20-22]. Here, we describe the production of CLEAs of the SPase from B. adolescentis that display exceptional thermal and operational stability.

$\rightarrow$ Fig. 1 


\section{Materials and methods}

\subsection{Materials}

Tert-butyl alcohol, glutaraldehyde, and sodium borohydride were purchased from Aldrich-Chemie, Fisher and Acros, respectively. All other reagents were purchased from Sigma-Aldrich.

\subsection{Enzyme production}

The SPase gene from B. adolescentis LMG 10502 was recombinantly expressed in E. coli XL10-Gold, under control of the constitutive promotor P34 [23]. The construction of the corresponding expression vector pCXhP34_SPBa will be described elsewhere. Transformed cells were cultivated in 11 shake flasks at 37 ${ }^{\circ} \mathrm{C}$ using LB medium supplemented with $100 \mathrm{mg} \mathrm{l}^{-1}$ ampicillin. After $8 \mathrm{~h}$ of expression, the cells were harvested by centrifugation $\left(7000 \mathrm{rpm}, 4{ }^{\circ} \mathrm{C}, 20 \mathrm{~min}\right)$. Crude enzyme preparations were prepared by enzymatic lysis of frozen pellets using the EasyLyse Bacterial Protein Extraction Solution (Epicentre). Cell debris was removed by centrifugation $\left(12000 \mathrm{rpm}, 4{ }^{\circ} \mathrm{C}, 30 \mathrm{~min}\right)$. The crude enzyme preparation was heat purified by incubation at $60{ }^{\circ} \mathrm{C}$ for $60 \mathrm{~min}$. Denaturated proteins were removed by centrifugation $\left(12000 \mathrm{rpm}, 4{ }^{\circ} \mathrm{C}, 15 \mathrm{~min}\right)$.

\subsection{CLEAs production}

Aggregates of SPase were prepared by adding $6 \mathrm{ml}$ of tert-butyl alcohol under agitation to $4 \mathrm{ml}$ of heat-purified SP enzyme $\left(1.2 \mathrm{mg} \mathrm{ml}^{-1}\right)$ at $\mathrm{pH}$ 7. After $30 \mathrm{~min}$, varying amounts of a $25 \%(\mathrm{v} / \mathrm{v})$ glutaraldehyde solution were added to cross-link 
the enzyme aggregate, and the mixture was kept under stirring for 15, 30, 60 or $120 \mathrm{~min}$. Reduction of the formed imine bond was achieved by adding $10 \mathrm{ml}$ of a solution containing $1 \mathrm{mg} \mathrm{ml}^{-1}$ sodium borohydride in $0.1 \mathrm{M}$ sodium bicarbonate buffer at $\mathrm{pH}$ 10. After $15 \mathrm{~min}$, another $10 \mathrm{ml}$ was added and allowed to react for 15 min. Finally, the CLEAs were separated by centrifugation (15 $\mathrm{min}$ at 12000 rpm) and washed five times with $0.1 \mathrm{M}$ phosphate buffer at $\mathrm{pH}$ 7. All the steps were performed in a thermoshaker (Eppendorf) at $750 \mathrm{rpm}$ and $4{ }^{\circ} \mathrm{C}$. The immobilization yield is defined as the ratio of the activity detected in the CLEA preparation and that present in the original enzyme solution.

\subsection{Activity assays}

The phosphorolytic activity of SPase was determined by measuring the release of the reducing sugar fructose from the non-reducing substrate sucrose with the bicinchonic acid (BCA) method [24]. The reactions were analysed in a discontinuous way, by inactivation samples $\left(5 \mathrm{~min}\right.$ at $\left.95^{\circ} \mathrm{C}\right)$ at regular intervals. One unit (U) of SPase activity corresponds to the release of $1 \mu$ mole fructose from $100 \mathrm{mM}$ sucrose in $100 \mathrm{mM}$ phosphate buffer at $\mathrm{pH} 7$ and $37{ }^{\circ} \mathrm{C}$. To determine phosphatase activity, the samples were also analysed for the release of glucose (from the $\alpha$-glucose-1-phosphate generated by SPase) with the glucose oxidase / peroxidase assay [25]. One unit (U) of phosphatase activity corresponds to the release of $1 \mu$ mole of glucose from $100 \mathrm{mM}$ sucrose in $100 \mathrm{mM}$ phosphate buffer at $\mathrm{pH} 7$ and $37^{\circ} \mathrm{C}$. When phosphatase activity was detected, this was subtracted from the values obtained by the BCA-method to calculate the net SPase activity. 
The protein concentration was measured with the Protein Assay kit from Pierce, using bovine serum albumin as standard.

\subsection{Stability assays}

To determine the thermostability of SPase, soluble or immobilized enzyme was incubated in $100 \mathrm{mM}$ phosphate buffer $\mathrm{pH} 7$ in a water bath at $60{ }^{\circ} \mathrm{C}$. At regular intervals, samples were inactivated and the residual activity was analysed using the BCA method. To evaluate the reusability of SPase CLEAs, the biocatalyst was used for several reaction cycles of $1 \mathrm{~h}$ at $60{ }^{\circ} \mathrm{C}$. The enzyme was recuperated by centrifugation (15 min at $12000 \mathrm{rpm}$ ) and washed five times with $0.1 \mathrm{M}$ phosphate buffer at $\mathrm{pH} 7$.

\section{Results and discussion}

\subsection{Production and purification of SPase}

The SPase gene from B. adolescentis LMG 10502 was recombinantly expressed in E. coli XL10-Gold. After chemo-enzymatic cell lysis, a crude enzyme preparation was obtained with a specific SPase activity of approximately $13 \mathrm{U}$ $\mathrm{mg}^{-1}$ at $37^{\circ} \mathrm{C}$. As the SPase is more stable than most endogenous E. coli proteins, the enzyme could be partially purified by means of heat treatment (Table 1). In this way, all phosphatase activity was removed, which would otherwise degrade the $\alpha$-glucose-1-phosphate (G1P) produced by SPase. 
After 1 hour incubation at $60{ }^{\circ} \mathrm{C}$, the specific activity increases to $29 \mathrm{U} \mathrm{mg}^{-1}$ and the concentration of soluble protein drops from 2.6 to $1.2 \mathrm{mg} \mathrm{ml}^{-1}$. The latter is completely due to the loss of contaminating proteins, as no decrease in SPase activity is observed under these conditions. Longer incubation times do not result in a further increase in specific activity. Although the final enzyme preparation is estimated to be only $20 \%$ pure, as judged by SDS-PAGE (not shown), a higher level of purity is not required for most applications and would probably not be economical at an industrial scale.

$\rightarrow$ table 1

\subsection{Production of SPase CLEAs}

The first step in the preparation of CLEAs consists of the aggregation of the enzymes, which can be achieved by the addition of salts, organic solvents or nonionic polymers [5]. The choice of the additive is important, because it can result in enzymes with slightly different three-dimensional structures. Ammonium sulfate is the most widely used precipitant for protein purification, but gave unsatisfactory results with SPase. High concentrations of the salt are required ( $70 \% \mathrm{w} / \mathrm{v}$ ) to aggregate this enzyme and generate a gelatinous suspension that is difficult to centrifuge. Precipitation was, therefore, performed with tert-butanol instead. A solvent concentration of $60 \%(\mathrm{v} / \mathrm{v})$ resulted in complete removal of SPase activity from the supernatant after centrifugation. The precipitate could be redissolved in phosphate buffer without loss of activity, indicating that the aggregation procedure does not damage the structural integrity of the protein. 
In the second step, the aggregated enzyme molecules are chemically cross-linked to obtain an immobilised biocatalyst. Glutaraldehyde (GA) is generally used for that purpose, as it contains two aldehyde groups that can form imine bonds with lysine residues from two enzyme molecules (Fig. 1). It is well known that the immobilization yield strongly depends on the incubation time of the cross-linking step as well as on the GA / protein ratio [26]. These parameters have, therefore, been optimized for the production of CLEAs of SPase (Fig. 2). A maximal immobilization yield of $31 \%$ could be achieved at a GA / protein ratio of $0.17 \mathrm{mg}$ $\mathrm{mg}^{-1}$ and an incubation time of 1 hour. Higher ratios and longer incubation times result in a considerable reduction in catalytic activity, most likely because glutaraldehyde then starts to react with residues in the active site. Indeed, this problem can sometimes be avoided by the use of polymeric cross-linkers that are too large to access the active site [27], but these have not been tested in this work. Even under optimal conditions, the activity recovered in the CLEA preparation is lower than that of the free SPase, which means that diffusion limitations are operative and/or that the catalytic site has undergone some kind of distortion.

$\rightarrow$ Fig 2

\subsection{Characterization of SPase CLEAs}

Many studies have shown that the activity and stability of an immobilized enzyme can differ considerably from that of its soluble counterpart $[28,29]$. Therefore, the properties of the CLEAs were compared with those of the native SPase. The 
optimal $\mathrm{pH}$ and temperature for phosphorolytic activity of the immobilized enzyme were found to be 6.0 and $75^{\circ} \mathrm{C}$, compared to 6.5 and $58{ }^{\circ} \mathrm{C}$, respectively, for the soluble enzyme (Fig. 3 and Fig. 4). Cross-linking thus results in an enzyme whose temperature optimum has increased with an impressive $17{ }^{\circ} \mathrm{C}$. Furthermore, the immobilized enzyme is active in a broader $\mathrm{pH}$-range, indicating a higher operational stability.

$\rightarrow$ Fig $3 \& 4$

To determine the thermostability of the SPase preparation, the enzyme was incubated at $60{ }^{\circ} \mathrm{C}$ and its residual activity was measured at several points in time. The CLEAs were found to retain full activity after 1 week incubation, whereas the free enzyme loses $20 \%$ of its activity after only $16 \mathrm{~h}$ incubation. The stability of the biocatalyst is, therefore, dramatically improved by the cross-linking process. As industrial carbohydrate conversions are preferably performed at $60{ }^{\circ} \mathrm{C}$, the properties of these CLEAs will undoubtedly allow the development of novel processes of high economic value.

One of the major advantages of immobilization is that it leads to an enzyme preparation that can be recycled, which often is a key determinant of its industrial potential. CLEAs can be easily recycled by either filtration or centrifugation [6], and the latter strategy has been used in our experiments. Centrifugation at high speeds $(12000 \mathrm{rpm})$ was found to be required for the precipitation of CLEAs and the complete removal of phosphorolytic activity from the supernatant. To evaluate 
the mechanical stability of the biocatalyst under these conditions, several reaction cycles of $1 \mathrm{~h}$ at $60{ }^{\circ} \mathrm{C}$ were performed with thorough washing in between. After ten cycles, no loss of activity could be detected, revealing the excellent operational stability of the new enzyme preparation.

\subsection{Production of G1P with SPase CLEAs}

To evaluate the efficiency of the SPase CLEAs in a production process, the phosphorolysis of sucrose into G1P was monitored at $60{ }^{\circ} \mathrm{C}$ and $\mathrm{pH} 7$ until maximal conversion. The reaction was performed with $500 \mathrm{U}$ of CLEAs in a solution containing $1 \mathrm{M}$ of sucrose and inorganic phosphate. After about $20 \mathrm{~h}$, the conversion was finished and 0.7 M G1P was produced. This corresponds to an equilibrium constant $\left(\mathrm{K}_{\mathrm{eq}}\right)$ of 5.63 , which is lower than the value previously determined at $30^{\circ} \mathrm{C}[15]$.

In view of the exceptional mechanical and thermal stability of the CLEAs, it should be possible to repeat this reaction at least seven times in one week time. In that way, more than $1 \mathrm{~kg}$ of G1P would be produced with only about $50 \mathrm{mg}$ of protein, which still would be fully active. This is the first report on a production process with SPase at elevated temperatures.

\section{Concluding remarks}

In this work, the preparation of cross-linked enzyme aggregates was found to be a simple but efficient strategy to increase the thermostability of the sucrose 
phosphorylase from Bifidobacterium adolescentis. These CLEAs remain fully active after one week incubation at $60{ }^{\circ} \mathrm{C}$ and can be recycled at least ten times for the repeated conversion of sucrose into a-glucose-1-phosphate. This low-cost and easy procedure should allow the development of industrial processes to exploit the different glycosylation reactions catalyzed by sucrose phosphorylase. 


\section{Acknowledgements}

The authors want to thank Flanders' Agency for Innovation by Science and Technology (IWT-Vlaanderen) for financial support (Grant SBO-50191).

The authors have declared no conflict of interest. 


\section{References}

[1] Sheldon, R.A., Enzyme immobilization: The quest for optimum performance. Adv. Synth. Catal. 2007, 349, 1289-1307.

[2] Brady, D., Jordaan, J., Advances in enzyme immobilisation. Biotechnol. Lett. 2009, 31, 1639-1650.

[3] Hanefeld, U., Gardossi, L., Magner, E., Understanding enzyme immobilisation. Chem. Soc. Rev. 2009, 38, 453-468.

[4] Bornscheuer, U.T., Immobilizing enzymes: How to create more suitable biocatalysts. Angew. Chem. Int. Ed. 2003, 42, 3336-3337.

[5] Cao, L.Q., van Rantwijk, F., Sheldon, R.A., Cross-linked enzyme aggregates: A simple and effective method for the immobilization of penicillin acylase. Org. Lett. 2000, 2, 1361-1364.

[6] Cao, L.Q., van Langen, L., Sheldon, R.A., Immobilised enzymes: carrierbound or carrier-free? Curr. Opin. Biotechnol. 2003, 14, 387-394.

[7] Tischer, W., Kasche, V., Immobilized enzymes: crystals or carriers? Trends Biotechnol. 1999, 17, 326-335.

[8] Abraham, T.E., Joseph, J.R., Bindhu, L.B.V., Jayakumar, K.K., Crosslinked enzyme crystals of glucoamylase as a potent catalyst for biotransformations. Carbohydr. Res. 2004, 339, 1099-1104.

[9] Lee, J.H., Yoon, S.H., Nam, S.H., Moon, Y.H. et al., Molecular cloning of a gene encoding the sucrose phosphorylase from Leuconostoc mesenteroides B-1149 and the expression in Escherichia coli. Enzyme Microb. Technol. 2006, 39, 612-620.

[10] Henrissat, B., A classification of glycosyl hydrolases based on amino-acidsequence similarities. Biochem. J. 1991, 280, 309-316.

[11] Goedl, C., Nidetzky, B., Sucrose phosphorylase harbouring a redesigned, glycosyltransferase-like active site exhibits retaining glucosyl transfer in the absence of a covalent intermediate. Chembiochem 2009, 10, 23332337.

[12] Sprogoe, D., van den Broek, L.A.M., Mirza, O., Kastrup, J.S. et al., Crystal structure of sucrose phosphorylase from Bifidobacterium adolescentis. Biochemistry 2004, 43, 1156-1162.

[13] Tedokon, M., Suzuki, K., Kayamori, Y., Fujita, S. et al., Enzymatic assay of inorganic phosphate with use of sucrose phosphorylase and phosphoglucomutase. Clin. Chem. 1992, 38, 512-515.

[14] Birnberg, P.R., Brenner, M.L., A one-step enzymatic assay for sucrose with sucrose phosphorylase. Anal. Biochem. 1984, 142, 556-561.

[15] Goedl, C., Schwarz, A., Minani, A., Nidetzky, B., Recombinant sucrose phosphorylase from Leuconostoc mesenteroides: characterization, kinetic studies of transglucosylation, and application of immobilised enzyme for production of alpha-D-glucose 1-phosphate. J. Biotechnol. 2007, 129, 7786.

[16] Kitao, S., Matsudo, T., Saitoh, M., Horiuchi, T. et al., Enzymatic synthesis of 2 stable (-)-epigallocatechin gallate-glucosides by sucrose phosphorylase. Biosci. Biotechnol. Biochem. 1995, 59, 2167-2169. 
[17] Sawangwan, T., Goedl, C., Nidetzky, B., Single-step enzymatic synthesis of (R)-2-O-alpha-D-glucopyranosyl glycerate, a compatible solute from micro-organisms that functions as a protein stabiliser. Org. Biomol. Chem. 2009, 7, 4267-4270.

[18] Goedl, C., Sawangwan, T., Mueller, M., Schwarz, A. et al., A highyielding biocatalytic process for the production of 2-O-(alpha-Dglucopyranosyl)-sn-glycerol, a natural osmolyte and useful moisturizing ingredient. Angew. Chem. Int. Ed. 2008, 47, 10086-10089.

[19] Goedl, C., Sawangwan, T., Wildberger, P., Nidetzky, B., Sucrose phosphorylase: a powerful transglucosylation catalyst for synthesis of alpha-D-glucosides as industrial fine chemicals. Biocatal. Biotransformation 2010, 28, 10-21.

[20] Bruins, M.E., Janssen, A.E.M., Boom, R.M., Thermozymes and their applications - a review of recent literature and patents. Appl. Biochem. Biotechnol. 2001, 90, 155-186.

[21] Vieille, C., Zeikus, J.G., Thermozymes: Identifying molecular determinants of protein structural and functional stability. Trends Biotechnol. 1996, 14, 183-190.

[22] Eijsink, V.G.H., Gaseidnes, S., Borchert, T.V., van den Burg, B., Directed evolution of enzyme stability. Biomol. Eng. 2005, 22, 21-30.

[23] De Mey, M., Maertens, J., Lequeux, G.J., Soetaert, W.K. et al., Construction and model-based analysis of a promoter library for E. coli: an indispensable tool for metabolic engineering. BCM Biotechnol. 2007, 18, 34-39.

[24] Waffenschmidt, S., Jaenicke, L., Assay of reducing sugars in the nanomole range with 2,2'-bicinchoninate. Anal. Biochem. 1987, 165, 337-340.

[25] Werner, W., Rey, H.G., Wielinge.H, Properties of a new chromogen for determination of glucose in blood according to god/pod-method. Z. Anal. Chem. 1970, 252, 224.

[26] Wilson, L., Manes, A., Soler, L., Henriquez, M.J., Effect of the degree of cross-linking on the properties of different CLEAs of penicillin acylase. Process Biochem. 2009, 44, 322-326.

[27] Mateo, C., Palomo, J.M., van Langen, L.M., van Rantwijk, F. et al., A new, mild cross-linking methodology to prepare cross-linked enzyme aggregates. Biotechnol. Bioeng. 2004, 86, 273-276.

[28] Clark, D.S., Can immobilization be exploited to modify enzyme-activity. Trends Biotechnol. 1994, 12, 439-443.

[29] Mateo, C., Grazu, V., Pessela, B.C.C., Montes, T. et al., Advances in the design of new epoxy supports for enzyme immobilization-stabilization. Biochem. Soc. Trans. 2007, 35, 1593-1601. 
Table 1 Heat purification of SPase from B. adolescentis

\begin{tabular}{ccccc}
\hline $\begin{array}{c}\text { Incubation at } 60^{\circ} \mathrm{C} \\
(\mathrm{min})\end{array}$ & $\begin{array}{c}\text { SPase activity } \\
(\mathrm{U} / \mathrm{ml})\end{array}$ & $\begin{array}{c}\text { Phosphatase activity } \\
(\mathrm{U} / \mathrm{ml})\end{array}$ & $\begin{array}{c}\text { Protein concentration } \\
(\mathrm{mg} / \mathrm{ml})\end{array}$ & $\begin{array}{c}\text { Specific activity } \\
(\mathrm{U} / \mathrm{mg})\end{array}$ \\
\hline 0 & 35.1 & 2.7 & 2.6 & 13.5 \\
20 & 35.2 & 0.7 & 1.6 & 22.0 \\
40 & 35.0 & 0.0 & 1.5 & 23.3 \\
60 & 35.1 & 0.0 & 1.2 & 29.3 \\
90 & 35.0 & 0.0 & 1.2 & 29.2 \\
\hline & \\
Assays were performed at $37{ }^{\circ} \mathrm{C}$ using $100 \mathrm{mM}$ sucrose in $100 \mathrm{mM}$ phosphate buffer $\mathrm{pH} 7$ as \\
substrate. SPase activity corresponds to the release of fructose, while phosphatase activity \\
corresponds to the release of glucose (from the $\alpha$-glucose-1-phosphate formed by SPase).
\end{tabular}




\section{Figure legends}

Fig. 1 General scheme for the production of cross-linked enzyme aggregates (CLEAs).

Fig. 2 The effect of the cross-linking ratio $(\bullet)$ and reaction time $(\circ)$ on the immobilization yield of SPase from B. adolescentis. The immobilization yield is defined as the ratio of the activity detected in the CLEA preparation and that present in the original enzyme solution.

Fig. 3 The effect of $\mathrm{pH}$ on the activity of soluble (०) and immobilized (•) SPase from $B$. adolescentis. Reactions were performed with $0.1 \mathrm{M}$ sucrose in a $0.1 \mathrm{M}$ phosphate buffer at $37^{\circ} \mathrm{C}$.

Fig. 4 The effect of temperature on the activity of soluble (०) and immobilized (•) SPase from $B$. adolescentis. Reactions were performed with $0.1 \mathrm{M}$ sucrose in a $0.1 \mathrm{M}$ phosphate buffer at $\mathrm{pH} 7$. 

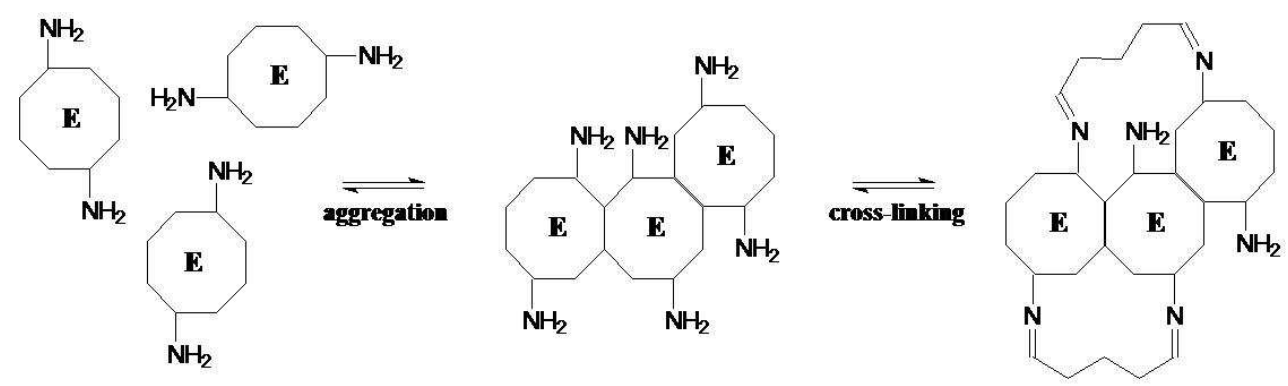

Fig. 1 General scheme for the production of cross-linked enzyme aggregates (CLEAs). $304 \times 93 \mathrm{~mm}(96 \times 96$ DPI) 
2

3

4

5

6

7

8

9

10

11

12

13

14

15

16

17

18

19

20

21

22

23

24

25

26

27

28

29

30

31

32

33

34

35

36

37

38

39

40

41

42

43

44

45

46

47

48

49

50

51

52

53

54

55

56

57

58

59

60

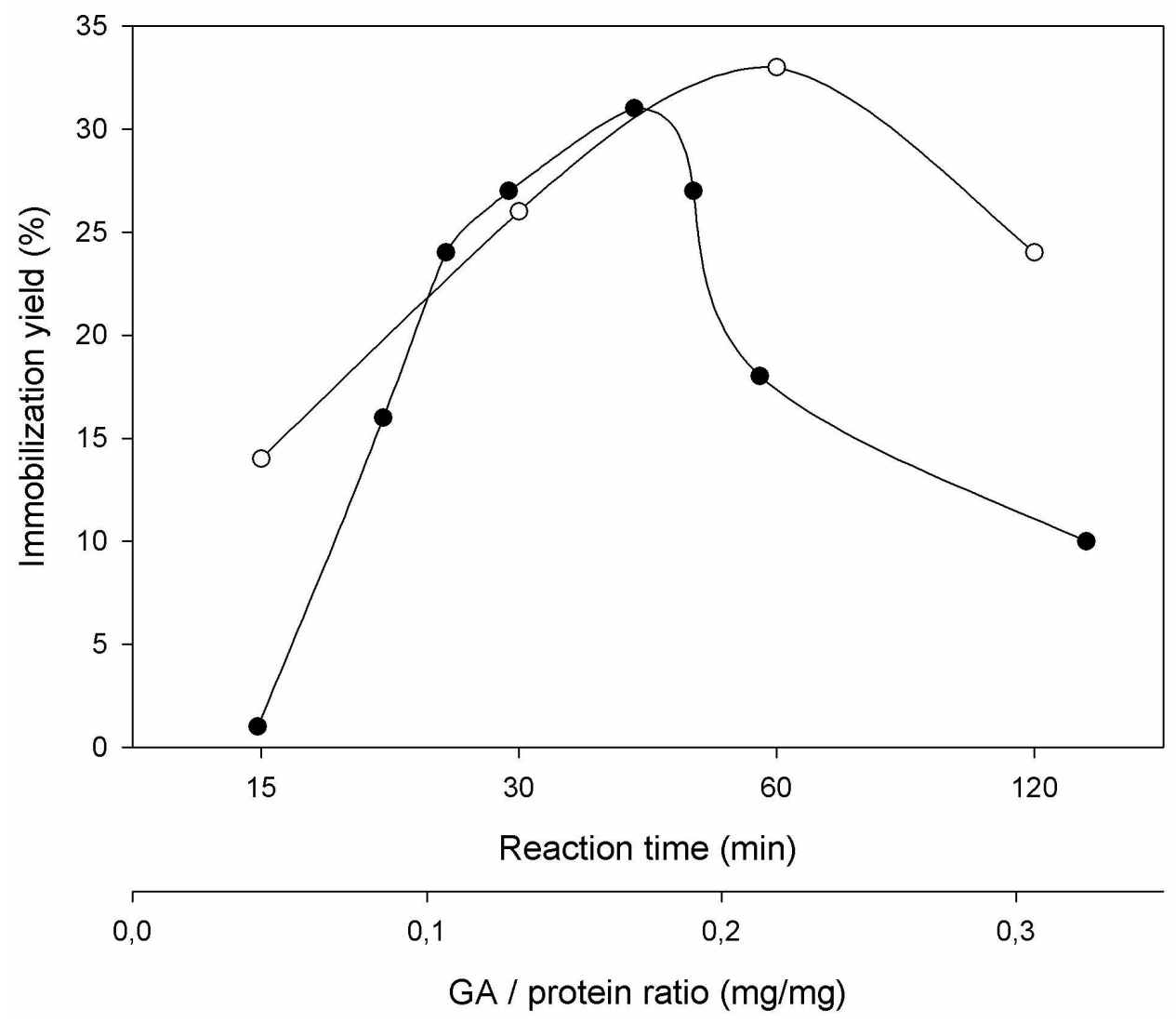

Fig. 2 The effect of the cross-linking ratio $(\bullet)$ and reaction time ( $(0)$ on the immobilization yield of SPase from B. adolescentis. The immobilization yield is defined as the ratio of the activity detected in the CLEA preparation and that present in the original enzyme solution.

$84 \times 83 \mathrm{~mm}(600 \times 600 \mathrm{DPI})$ 


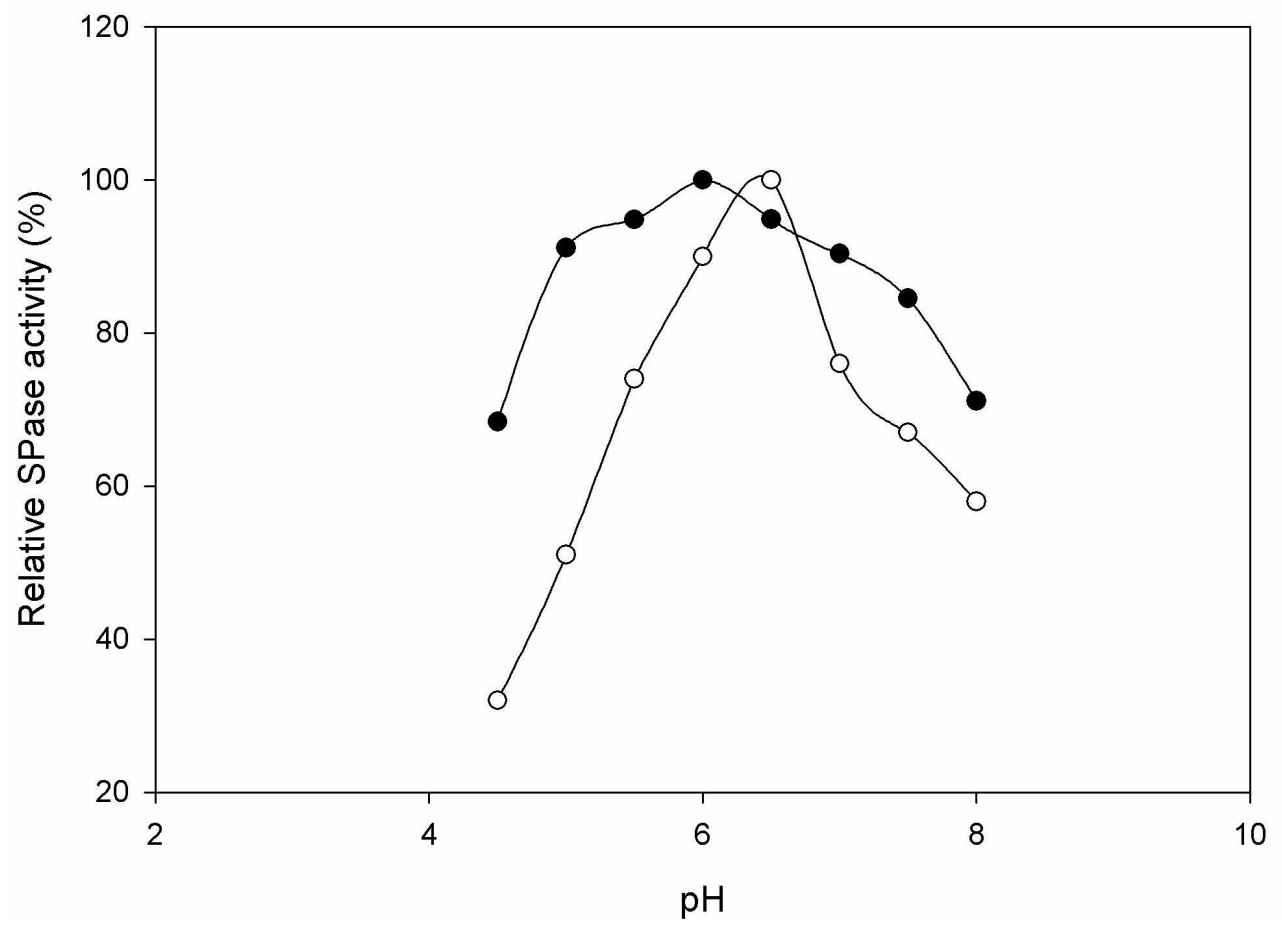

Fig. 3 The effect of pH on the activity of soluble $(0)$ and immobilized $(\bullet)$ SPase from B. adolescentis. Reactions were performed with $0.1 \mathrm{M}$ sucrose in a $0.1 \mathrm{M}$ phosphate buffer at $37^{\circ} \mathrm{C}$. $84 \times 65 \mathrm{~mm}(600 \times 600 \mathrm{DPI})$ 
1

2

3

4

5

6

7

8

9

10

11

12

13

14

15

16

17

18

19

20

21

22

23

24

25

26

27

28

29

30

31

32

33

34

35

36

37

38

39

40

41

42

43

44

45

46

47

48

49

50

51

52

53

54

55

56

57

58

59

60

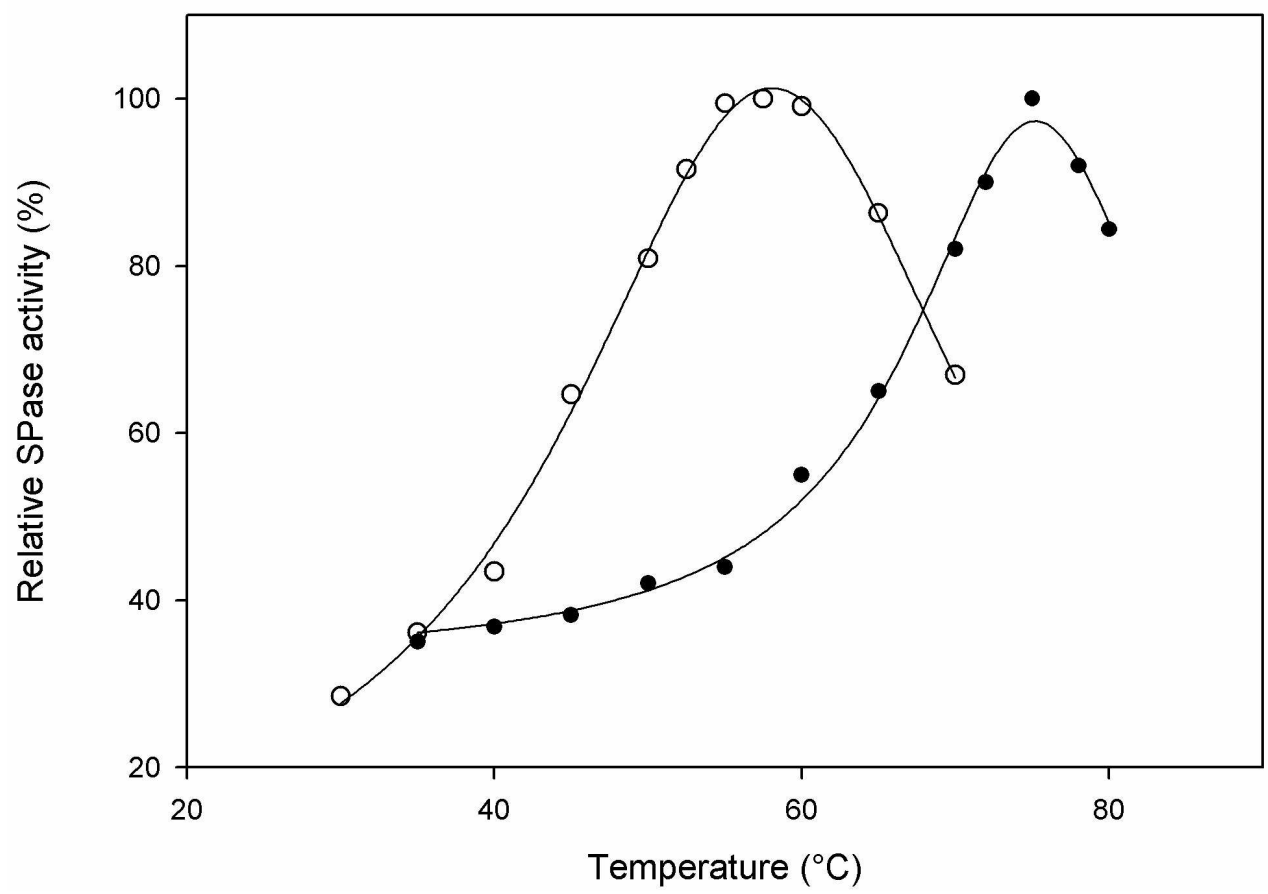

Fig. 4 The effect of temperature on the activity of soluble (०) and immobilized (•) SPase from B. adolescentis. Reactions were performed with $0.1 \mathrm{M}$ sucrose in a $0.1 \mathrm{M}$ phosphate buffer at $\mathrm{pH} 7$. $84 \times 63 \mathrm{~mm}(600 \times 600 \mathrm{DPI})$ 